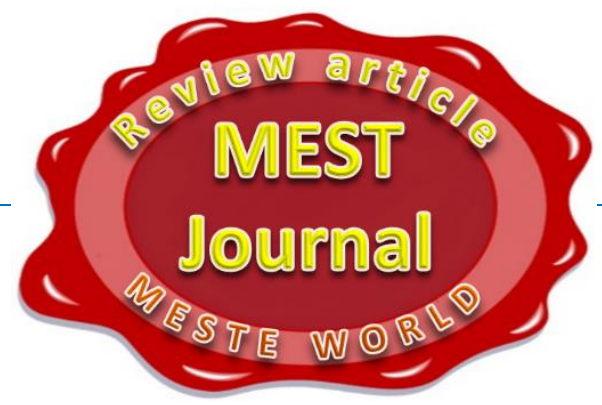

\title{
TAX HARMONIZATION ASPECTS OF SEE REGIONAL INTEGRATION PROCESSES
}

\author{
Georgi Ranchev \\ UNWE, Finance and Accounting Faculty, Sofia, Bulgaria \\ CMESTE \\ JEL Category: F13, F15, H25
}

\begin{abstract}
Six of the countries in Southeast Europe - Albania, Bosnia and Herzegovina, Macedonia, Montenegro, Serbia and UNMIK can still be considered as small and relatively isolated from an economic point of view. It seems that CEFTA 2006 as a separate effort of regional integration in Southeast Europe is not likely to have a substantial positive effect on the economic development of the region. Recent strategic theoretical and empirical studies show that the short-term economic implications of regional integration between developing countries are ambiguous. It seems that the main argument in favor of deeper regional integration between the six Southeast Europe countries will be the increased security through cooperation. The harmonization and coordination of the tax and customs legislation is of specific importance for the successful operation of CEFTA 2006. The maintenance of clear rules, in line with the European requirements regarding corporate and indirect taxation and control is of substantial importance for securing long-term fiscal stability in the region. An agenda for sustainable growth of the SEE-6 countries is much needed to stimulate further reforms orientied at the succesful accession of the region in the European Union.
\end{abstract}

Keywords: SEE, CEFTA 2006, regional integration, tax harmonization

\section{INTRODUCTION}

In 2016 six of the countries in Southeast Europe usually referred as the Western Balkans - Albania, Bosnia and Herzegovina, Macedonia, Montenegro, Serbia and UNMIK (hereinafter SEE - 6) can still be considered as small and relatively isolated from an economic point of view. It could also be argued that stabilization in Southeast Europe is possible only if higher speed of economic growth and deeper trade integration is reached. In this way the economic isolation of the

The address of the author:

Georgi Ranchev

跮= ranchev72@gmail.com countries can be considered as one of the main obstacles towards faster and more sustainable economic development in the region.

The processes of regional integration in the SEE region can be traced back to 2001 when seven countries in Southeast Europe: Albania, Bosnia and Herzegovina, Bulgaria, Croatia, Macedonia, Romania and FR Yugoslavia signed in Brussels a Memorandum of Understanding on the establishment of a Free Trade Zone in the region by the end of 2002 on the basis of bilateral free trade agreements. This Memorandum also expressed the intention of these countries to harmonize their legislation with that of the 
European Union including the harmonization of tax and customs legislation.

15 years after the signing of the Memorandum of Understanding a significantly different situation can be observed:

- Bulgaria, Croatia and Romania joined Slovenia and Greece in the European Union and in 2014 Albania has finally received EU candidate status and lined up with Turkey, Macedonia, Montenegro and Serbia;

- FR Yugoslavia no longer exists and we have now Serbia, Montenegro and UNMIK (hereinafter "Kosovo") separated.

- From EU perspective Bosnia and Herzegovina and Kosovo are considered "potential candidate countries". Albania, Bosnia and Herzegovina, Macedonia, Montenegro and Serbia have Stabilization and Association Agreements (SAA) in place, while Kosovo whose limited recognition has complicated its relationship with the EU, has only initialed a SAA.

- CEFTA is again completely reshaped as a multilateral trade liberalization vehicle and the current members are Albania, Bosnia and Herzegovina, Macedonia, Moldova, Montenegro, Serbia and Kosovo. The existing network of free trade agreements was cancelled and replaced by CEFTA 2006 agreement.

CEFTA 2006 agreement contains special provisions regarding liberalization of trade in industrial and agricultural products, technical barriers to trade, rules of origin and customs cooperation and the new trade issues such as strengthening cooperation in trade in services, investment, public procurement and intellectual property rights. The main objective of CEFTA 2006 is to facilitate the expansion of trade in goods and services and foster investment by means of fair, stable and predictable rules. It is expected that the Agreement will provide the necessary conditions for the members of CEFTA 2006 to prepare for EU accession, which was the agenda successfully achieved by the previous and founding members of CEFTA.

SEE - 6 group, which is the main focus of the current analysis, has a population of more than 18 million people and a territory of 207,821 square kilometers. The economies although having positive growth rates with the exception of Serbia are relatively small in terms of GDP and GDP/capita. The total GDP for SEE-6 is around USD 97 billion based on the data of CIA World Factbook (CIA, 2015). The unemployment rates in SEE - 6 are also very high - lowest in Serbia at $17.6 \%$ and highest in Bosnia and Herzegovina at $43.6 \%$.

The trade balances for all the countries are negative as the total trade balance for SEE- 6 is USD 19.9 billion. According to CEFTA statistics (CEFTA, 2015) for the first half of 2014 the share of the countries in imports of CEFTA is around 9\%, while the share of countries in export of CEFTA is around $17 \%$. Compared to other South-South regional integration agreements (RIAs) CEFTA is within the group of relatively strong trade blocks like ASEAN and MERCOSUR (Schiff \& Winters, 2003, p. 66).

\section{RESEARCH ON REGIONAL INTEGRATION}

The complexities of regional integration are quite successfully summarized Mr. Masood Ahmed, a former Director of the International Economics Department of the World Bank in the foreword of series of World Bank policy research working papers (e.g. Policy Research Working Paper Series No. 1750 (Blomstrom \& Kokko, Regional Integration and Foreign Direct Investment: A Conceptual Frmework and Three Cases, 1997)):

"As regional trading arrangements (RTAs) have spread, enlarged and deepened over the last decade, they have posed challenges to economists on both intellectual and policy levels. On the former, do RTAs stimulate growth and investment, facilitate technology transfer, shift comparative advantage towards high value-added activities, provide credibility to reform programs, or induce political stability and cooperation? Or do they, on the other hand, divert trade in inefficient directions and undermine the multilateral trading system?

The answer is probably "all of these things, in different proportions according to the particular circumstances of each RTA." This then poses the policy challenge of how best to manage RTAs in 
order to get the best balance of benefits and costs. For example, should technical standards be harmonized and, if so, how; do direct or indirect taxes need to be equalized; how should RTAs manage their international trade policies in an outward-looking fashion?"

What could be the possible economic implications of CEFTA 2006 and further EU accession for the SEE - 6 countries on FDI, growth and taxation? The following brief analysis is based to a greatest extent on the conclusions of various theoretical and empirical studies relevant to similar type of regional trade integration discussed in the present article. From theoretical perspective the specialized literature (Schiff \& Winters, 2003, p. $66)$ identifies three main types of trade integration:

1. "North - North" integration between developed countries (EEC, Canada joining CUSFTA);

2. "North - South" integration between developed and developing countries (Mexico joining NAFTA);

3. "South - South" integration between developing countries (ASEAN, MERCOSUR, CEFTA).

This division is quite important as the economic implications of the various RIAs may vary substantially depending on the type of economic integration perceived. In the subsequent analysis the focus will be mainly on the "North - South" and "South - South" models as obviously CEFTA 2006 or Southeast Europe consists of developing countries.

\subsection{FDI and Regional Integration}

Undoubtedly there is some correlation between the levels of foreign direct investment (FDI) and the degree of trade integration. However, depending on the economic status of the countries (North or South) involved in the trade integration processes, the impact of trade integration on the inflows or outflows of FDI may differentiate a lot. A number of additional factors such as political, trade protection or administrative developments, geographical location and infrastructure are relevant to FDI allocation as well. At the same time, additional determinants of such processes are the character of the already existing FDI and the time dimension (detailed analysis by (Blomstrom \& Kokko, 1997)).

The most immediate result of a trade integration process is the elimination or reduction of tariff barriers between the countries part of the RIAs (see also (Bhagwati, Protectionism, 1988)). In its turn, the reduced tariff barriers may lead to a decrease in intra-regional FDI, as a substitute for the increased trade between the countries. Thus, since there is a common market, there is no point of further investments in the region made by local companies - i.e. the comparative benefits of moving or spreading production to the other target country are less since the customs duties were reduced. One of the most important dynamic effects is the "reallocation of production resources to more closely reflect of regional comparative advantages" (Blomstrom \& Kokko, 1997, p. 11).

Thus, although outward FDI is likely to increase, the precise effects for each country within the RIA cannot be easily identified. MERCOSUR is a typical example of South - South integration between the countries of Argentina, Brazil, Paraguay and Uruguay. The initial empirical studies on the impact of the establishment of MERCOSUR on FDI suggest that macroeconomic stability is a more important determinant of FDI than is regional trade integration itself. As a result the outward FDI has increased substantially. However, it can be noticed that FDI flows are not distributed equally among the MERCOSUR countries. As far as Brazil and Argentina possess more locational advantages than Uruguay and Paraguay, the bulk of FDI is likely to be focused there in the short and medium term. Schiff and Winters, argue that South-South RIAs are unlikely to add credibility and may even hinder FDI if not accompanied by liberalization with the rest of the world (Schiff \& Winters, 2003, p. 17).

\subsection{Regional Integration and Growth}

Recent studies have explored whether the trade openness of the economies, their market size and the relevant economic development of countries that are close geographically have any positive impact on growth in the home country. In 1998, Athanasios Vamvakidis (Vamvakidis, 1998, p. 251) published a report on the correlation between regional integration and economic growth. Based 
on the analysis and the empirical evidence gathered, the author concludes that "countries with open, large, and more developed neighboring economies grow faster than those with closed, smaller, and less developed neighboring economies". The study concludes that based on the empirical models, the small countries participating in North - South integration will face faster growth. However, the tests performed with regard to the correlation between growth and regional integration under 4 distinct RIAs (ASEAN, ANCON, CACM and UDEAC) show negative results. The author explains these results with the fact that the members were "small, highly protected and similar in their economic endowments". Subsequent research showed mixed results as "the net impact on a country's growth of trading with relatively less developed countries is an empirical question: it is negative if the relative income effect dominates and positive if the relative growth effect dominates" (Aurora \& Vamvakidis, 2004, p. 4). On the other hand, the results of the same test for the European Union are positive for the same period and these results confirm that actually EU regional integration had positive impact on growth.

\subsection{Integration and Harmonization of Taxes}

How does regional trade integration affect corporate tax rates in the partner countries? This is one of the questions that have to be addressed prior to entering in a RIA. In summary, the removal of barriers to movement of goods and services across borders will lead to changes in the allocation of resources (see (De Bonis, Regional Integration and Factor Income Taxation, 1997). Thus, partner countries will face the necessity of establishment of a certain level of income tax uniformity. Such uniformity could be achieved through tax harmonization or through competition. However, in the case of competition, the income tax rates are likely to fall below their optimum limits, which will lead in its turn to losses in budget revenues. More recent research on the effects of income tax harmonization in the context of regional integration (see (De Bonis, Regional Integration and the Co-ordination of Capital Income Taxation, 2002, p. 1)) suggests that „international tax uniformity does not appear to be the preferable solution".

Harmonization of income taxes is far from being accomplished even in the European Union. The harmonization of income taxes does not simply mean harmonization of tax rates. In order, to achieve considerable level of harmonization, the countries should implement similar if not the same basis for corporate taxation. For various reasons: historical, political, social and economic, this is almost impossible in the near future. On the other hand, competition among the states will lead to constant downsizing of the rates and/or introduction of tax incentives. What can be the solution in such case? One useful suggestion is that some sort of international tax coordination is needed (see also (De Bonis, Regional Integration and Factor Income Taxation, 1997)) in order to limit the undesirable effects of revenue losses in the partner countries.

Another, important issue in this respect is the elimination of double taxation of income by way of Double Tax Treaties (DTT). The differences in the treatment of certain types of income such as dividends, interest and royalties can partly be eliminated between each pair of partner countries in the form of a DTT. Thus, the network of the existing DTT should be considered, prior to entering in the RIA. It can be presumed that DTTs usually encourage cross border trade and investment, and it is advisable that the countries in the RIA enter into DTTs with each other as well.

The correlation between RIA and personal income taxation is not of such importance. This can be partly explained by the fact that additional contributions (social, health, unemployment, etc.) affect the amount of take-in-home money of the employees. Substantial distortions in the allocation of labor resources among the countries in the region can only be expected if there is a considerable difference in the living standards and real wages of the countries in the region (see also in (Bhagwati \& Hudec, Fair Trade and Harmonization: Prerequisites for Free Trade, Volume 2, 1996)). Additional restrictions on the movement of people (visas, work permits, etc.) can also prevent such reallocation.

A certain degree of harmonization of indirect taxes is important for the success of each RIA (see also 
(De Bonis, Regional Integration and Commodity Tax Harmonization, 1997)). One of the main concerns is relevant to the level of cross-border shopping. Once, the tariff barriers are removed, the residents of the bordering territories are more likely to shop across the borders. If there are considerable differences in the rates of the indirect taxes applied by countries in the RIA, the residents of the "higher" rate country are more likely to shop in the "lower" rate country. Such problems are still acute in the European Union. The difference is even sharper in the case of exemption from indirect taxes of specific groups of goods. However, harmonization of tax rates only is not the perfect solution. Harmonization of the overall legislation and basis for taxation together with the tax rates may prove far more efficient. This reallocation of consumption will lead to losses in budget revenues of the "higher" income country. As far as the mechanisms for compensation of such "foregone" budget revenues is practically impossible, harmonization is the only possible solution for avoiding most of the undesirable effects.

\section{THE IMPACT OF CEFTA 2006}

It should be noted that some of the theoretical implications discussed above are contradictory or overlapping based on the fact that two parallel processes of trade integration are taking place in the region: on one hand it is the free trade between the SEE - 6 countries and on the other the process of further trade liberalization and accession to the European Union. Furthermore, the various implications of regional trade integration are intrarelated - i.e. as the case of FDI and taxation.

\subsection{CEFTA 2006: FDI, growth and taxation}

On the theoretical level one of the most likely results of the operation of CEFTA 2006 will be the decrease in intra-regional FDI as a substitute for increased regional trade. However, this negative effect will be of minor importance, since intraregional FDI is not substantial by the moment. On the other hand, it could be anticipated that outside FDI will be increased with deepening of the regional integration processes. The countries having the best locational advantages such as
Serbia, Montenegro and Albania due to macroeconomic and political stability will attract the most of FDI inflows. The discussed above recent studies suggest that in the case of SouthSouth integration like CEFTA 2006 for the countries in Southeast Europe, macroeconomic stability will be a more important factor than regional integration itself. As it seems that the political and economic situation in the region will continue to be volatile FDI inflows are not likely to change significantly in the short and medium term.

The discused ambiguous effects on FDI take into account the establishment of RIA like CEFTA 2006 as a single factor. However, all the countries in the region have engaged in liberalization of trade with the European Union - their largest trade partner. This type of integration (North-South) leads in general to positive FDI inflows in the Southern economies. In this way, these slightly negative implications on FDI for SEE-6 countries may be partially or fully compensated. However, the presence of macroeconomic stability will be once again an important factor.

The analyzed empirical studies on the correlation between growth and regional integration of the same type as CEFTA 2006 in Southeast Europe show that no such direct correlation can be found based on the empirical evidence or the effects are rather ambiguous. Once again, the process of increasing trade liberalization between the SEE 6 countries and the European Union as a separate process should lead to more positive effects in terms of economic growth as compared to the process of regional trade integration by itself. In the countries in Southeast Europe, as well as on world scale, there is a common tendency of the decrease of the corporate tax rates.

The corporate tax and VAT rates for 2015 for SEE6 countries according to information from KPMG Global (KPMG, 2015) are shown in Table 1.

As it can be seen from the table, the levels of the corporate tax rates for the year 2015 are rather low. This tendency can be explained partly with the growing globalization of the business and implementation of new technologies, the increased exposures, relevant to the investments in the countries of Southeast Europe. As far as the business and the capital are becoming more mobile and the political and economic risk is 
substantial, the countries in the region are facing a significant pressure to provide competitive corporate tax rates, which resulted in a minimization of corporate tax rates to very low levels.

Table 1. SEE-6 Tax Systems in 2015

\begin{tabular}{|l|c|c|}
\hline & $\begin{array}{c}\text { Corporate Tax } \\
\text { Rate }\end{array}$ & $\begin{array}{c}\text { Standard VAT } \\
\text { Rate }\end{array}$ \\
\hline ALB & 15 & 20 \\
\hline B\&H & 10 & 17 \\
\hline KOS & 10 & 16 \\
\hline MAC & 10 & 18 \\
\hline MON & 9 & 19 \\
\hline SER & 15 & 20 \\
\hline
\end{tabular}

The harmonization and coordination of the tax and customs legislation is of specific importance for the successful operation of CEFTA 2006. The maintenance of clear rules, in line with the European requirements in respect to corporate and indirect taxation and control is of substantial importance for securing long-term fiscal stability in the region.On the other hand, there is a significant risk for the SEE - 6 countries if a compatible tax and customs legislation is not present. With the removal of the trade barriers, the differences between the tax legislation become apparent especially with regard to the VAT and the excise duties. In this way, if there would be significant discrepancies in the applicable VAT and excise duty rates, an unexpected growth of the crossborder trade could be observed, which under equal conditions would lead to a decrease of the budget revenues in the countries, which apply higher rates of indirect taxes. At the same time bigger differences in the corporate rates might have a substantial impact on the decision of the potential investors to prefer a specific country for investment among all other countries in the region.

\subsection{Harmonization and FDI in the Region}

The problems, related to the re-distribution of the investment flows, from the so-called tax competition perspective, are a painful topic from a long time even for the countries within the European Union (Commission, 2015). In practice the amount of potential foreign investments from an international perspective and particularly in the SEE region is a rather limited, for the attraction and taxation of which a fierce struggle between the governments of the countries in Southeast Europe is in place. Recent research suggests that "the use of investment incentives focusing on foreign firms, although motivated in some cases from a theoretical point of view, is generally not an efficient way to raise national welfare" (Blomstrom \& Kokko, The Economics of Foreign Direct Investment Incentives, 2003, p. 1). Regarding the relationship between FDI and corporate tax incentives empirical analysis supports the concept that taxes are important factor if the SEE countries become "close substitutes concerning the location of investment" (Blazic \& Vlahinic, 2006, p. 23). Further to the above analysis, it is of primary importance that the countries in the region coordinate properly their tax policies and investment tax incentives. Engagement in tax competition and further downsizing of tax rates and/or tax incentives will lead to substantial budget losses.

It is clear that the economic effects of macroeconomic and fiscal stabilization through tax and customs harmonization as well as improved control can play more significant role in the economic stabilization in the region than regional trade integration alone. However, it should be noted that the outcome of CEFTA 2006 should not be measured by economic indicators only. There are a number of non-economic implications that are important as well and could not be verified by amounts in foreign currency, shares, ratios and percentages.

Based on the above analysis it can be argued that deeper regional integration in Southeast Europe may have significant non-economic implications, which are positive for the long-term development of the region as a whole. It seems that the main argument in favor of the existing RIA between SEE - 6 countries will be the increased security through cooperation. The countries in Southeast Europe "will have to prove their readiness to overcome their mutual turbulent past and to leave it to historians" (Kostovska, 2009, p. 95). 
While the economic implications of CEFTA 2006 itself may prove ambiguous especially when compared with the effects of trade liberalization with the European Union, it can be anticipated that the RIA will decrease the level of bureaucracy, smuggling and corruption. At the same time trade liberalization in the region could have a positive impact on institution building, environment and health and protection of intellectual property rights.

\section{SEE AGENDA FOR SUSTAINABLE GROWTH}

One possible solution for the common problems of the SEE - 6 countries could be the establishment of a roadmap for sustainable growth which could serve as agenda for the governments of the Western Balkans and the EU to stabilize economically the region. This roadmap for sustainable growth could the next step for achieving deeper regional integration before the countries join the European Union. The roadmap could encompass the following measures for achieving sustainable growth in the region:

- Active support from the international institutions of the aspirations for EU membership of the SEE - 6 countries with accession in the next 5 - 10 years;

- Setting up targets and constant monitoring the levels of budget deficits as well as maintaining macroeconomic stability;

- Coordination of the efforts and identifying ways to increase FDI through improved infrastructure and legal environment;

- Coordination of the reforms in the tax and customs legislation oriented at further harmonization with EU legislation;

- Commitment of the governments to further fiscal consolidation through improved control mechanisms with active measures to limit corruption and bureaucracy;

- Focus of the governments on educational, health and social security reforms focused on integration of minorities and reduction of youth unemployment;
- Strengthening the role of the Regional Cooperation Council and active participations of experts in the working groups monitoring progress and setting the agenda.

Such an ambitious program could be achieved only through the coordinated efforts of the governments of the SEE- 6 countries with the support of the EU and international financial institutions. It would be very negative for the longterm economic development of the region if the debates over the migrant crisis or the exit of one or another EU Member State shift the agenda of the EU accession of the SEE - 6 countries in the indefinite future.

It could be argued that the vague prospects of EU membership can change the political and geostrategical orientation of the countries in the region into hardly predictable directions depending on the current interests of blocks outside of the EU thus increasing the uncertainty even to higher levels than the existing ones. Further destabilization of the SEE region can prove to be more costly and detrimental than setting a predictable path of EU membership and integration in front of the SEE-6 countries.

\section{CONCLUSIONS}

The countries in Southeast Europe can still be considered as small and relatively isolated from an economic point of view. It seems that CEFTA 2006 as a separate effort of regional integration is not likely to have a substantial positive effect on the economic development of the region. Recent strategic theoretical and empirical studies show that the short-term economic implications of regional integration between developing countries are ambiguous. It seems that the main argument in favor of deeper regional integration between SEE -6 countries will be the increased security through cooperation. The harmonization and coordination of the tax and customs legislation is of specific importance for the successful operation of CEFTA 2006.

The maintenance of clear rules, in line with the European requirements regarding corporate and indirect taxation and improved control mechanisms is of substantial importance for securing long-term fiscal stability in the region. An 
agenda for sustainable growth of the SEE-6 reforms orientied at the succesful accession of the countries is much needed to stimulate further region in the European Union.

\section{WORKS CITED}

Aurora, V., \& Vamvakidis, A. (2004). How Much Do Trading Partners Matter for Economic Growth? IMF Working Paper, WP/04/26 February, 4.

Bhagwati, J. (1988). Protectionism. Cambridge, MA: The MIT Press.

Bhagwati, J., \& Hudec, R. E. (1996). Fair Trade and Harmonization: Prerequisites for Free Trade, Volume 2. Cambridge, MA: The MIT Press.

Blazic, H., \& Vlahinic, N. (2006). FDI Determinants in Southeast European Countries with Special Reference to Tax Incentives. Economic Studies Journal .

Blomstrom, M., \& Kokko, A. (1997). Regional Integration and Foreign Direct Investment: A Conceptual Frmework and Three Cases. Policy Research Working Paper Series No. 1750.

Blomstrom, M., \& Kokko, A. (2003). The Economics of Foreign Direct Investment Incentives. NBER Working Paper Series No. 9489, February.

CEFTA. (2015). CEFTA. Retrieved from http://www.cefta.int

CIA. (2015). The World Factbook - CIA. Retrieved from : https://www.cia.gov/library/publications/theworld-factbook

Commission, E. (2015, 6 17). Retrieved from http://ec.europa.eu/taxation_customs/resources/ documents/taxation/company_tax/fairer_corporate_taxation/com_2015_302_en.pdf

De Bonis, V. (1997). Regional Integration and Commodity Tax Harmonization. Policy Research Working Paper No. 1848, the World Bank.

De Bonis, V. (1997). Regional Integration and Factor Income Taxation. Policy Research Working Paper No. 1849, The World Bank.

De Bonis, V. (2002). Regional Integration and the Co-ordination of Capital Income Taxation. Economic Notes 31, 79-108.

Kostovska, L. (2009). CEFTA-2006 Trade Cooperation. Third International Conference Regional Cooperation and Economic Integration Challanges and Opportunities, (pp. 91-100). Skopje.

KPMG. (2015). KPMG Global. Retrieved from http://www.kpmg.com/Global/en/services/Tax/tax-toolsand-resources/

Schiff, M., \& Winters, L. A. (2003). Regional integration and Development. IBRD/the World Bank.

Vamvakidis, A. (1998). Regional Integration and Economic Growth. The World Bank Economic Review Vol. 12, No.2.

Received for publication: $\quad 24.02 .2016$

Revision received: $\quad 26.03 .2016$

Accepted for publication: $\quad$ 10.06.2016 


\section{How to cite this article?}

Style - APA Sixth Edition:

Ranchev, G. (2016, July 15). Tax harmonization aspects of see regional integration processes. (Z. Čekerevac, Ed.) MEST Journal, 4(2), 161-169. doi:10.12709/mest.04.04.02.18

Style - Chicago Sixteenth Edition:

Ranchev, Georgi. 2016. "Tax harmonization aspects of see regional integration processes." Edited by Zoran Čekerevac. MEST Journal (MESTE) 4 (2): 161-169. doi:10.12709/mest.04.04.02.18.

Style - GOST Name Sort:

Ranchev Georgi Tax harmonization aspects of see regional integration processes [Journal] // MEST Journal / ed. Čekerevac Zoran. - Belgrade : MESTE, July 15, 2016. - 2 : Vol. 4. - pp. 161-169.

Style - Harvard Anglia:

Ranchev, G., 2016. Tax harmonization aspects of see regional integration processes. MEST Journal, 15 July, 4(2), pp. 161-169.

Style - ISO 690 Numerical Reference:

Tax harmonization aspects of see regional integration processes. Ranchev, Georgi. [ed.] Zoran Čekerevac. 2, Belgrade : MESTE, July 15, 2016, MEST Journal, Vol. 4, pp. 161-169. 